\title{
Cadicologist Study of Personal Letters Manuscript of Poet R. Ng. Ranggawarsita
}

\author{
Supana $^{1}$, W. Hendrasaputra ${ }^{2}$, Supardjo $^{3}$, Endang Tri Winarni ${ }^{4}$, Sutarjo $^{5}$, \\ Sisyono Eko Widodo ${ }^{6}$ \\ Universitas Sebelas Maret, Indonesia \\ $\left\{\underline{\text { supana } 77 @ \text { staff.uns.ac.id }}{ }^{1}\right.$ \}
}

\begin{abstract}
R. Ng. Ranggawarsita is one of poets who was highly productive in his era. His works contain many phylosophical values that are very important for human character development. The personal life of R. Ng. Ranggawarsita is also important to be revealed to complete how his life background is thoroughly. The personal letters of $\mathrm{R}$. $\mathrm{Ng}$. Ranggawarsita are the reflection of how the personal life of the poet was. Cadiocologist study investigated the form of Javanese script used in writing the letter, how was the language variety used in writing the letter, and the content of the letter made by Ranggawarsita. This research was descriptive qualitative research. Data in this research were personal letters text of R. Ng. Ranggawarsita and the information related to those letters. The data resources in this research were the personal letters of $\mathrm{R}$. Ng. Ranggawarsita published by Literature Foundation Surakarta at page sastra.org, consisted of 26 letters. The technique of data collection was by using content analysis, photography, and deep interview (in-depth interview). Data analysis used interactive model analysis namely the interaction of three analysis components covering data reduction, data presentation, and taking conclusion and its verification. The finding of this study was physically the personal letters text of R. Ng. Ranggawarsita that was handwritten (strip) in the ink on paper in Javanese script and Javanese letters and the language used was Javanese variety manners (krama). In addition to the widely used vocabulary of Inggil manners and Andhap manners (Krama Inggil and Krama Andhap), the vocabulary of Bagasa Kedhaton (Kingdom) was also used. The background related to the contents contained in the personal letter was the existence of various kinds of problems of daily life personally $\mathrm{R}$. $\mathrm{Ng}$. Ranggawarsita, whether on social, economic, work issues, or in his friendly relations with the Dutch people.
\end{abstract}

Keywords: R. Ng. Ranggawarsita, scripts, personal letters, codicology

\section{Introduction}

Research on R. Ng. Ranggawarsita, as a poet at the palace of Surakarta, has been undertaken until now largely from the stereotypical view on the poet. The real life of $\mathrm{R}$. $\mathrm{Ng}$. Ranggawarsita and the details of his personal life have not been disclosed. Therefore, this study will reveal another side of the life of $\mathrm{R}$. Ng. Ranggawarsita, which is reflected in the manuscripts of his personal letters that stored in Foundation of Sastra Lestari in Surakarta. There has not been much research on manuscripts containing letters, even though research on letters can reveal interesting aspects of past life. Titik Pudjiastuti (2007) has conducted research on letter manuscripts of the Cirebon Kanoman codicologically which discussed the ins and outs of letters, writing and the 
language used in the letter [1] . Hazmirullah (2020) also examined the Cianjur regent's letter for Rafles which focused on the use of Latin letters and Malay in the letter [2].

Meanwhile, Hafiful Hadi Sunliensyar (2019) Royal Letters to the rulers of Kerinci which focused on the content of the text and its historical background [3]. It has become a common understanding in the tradition of script copying in which the manuscript is copied in accordance with the needs of the user. This results in gaps between the manuscripts written by the author and the manuscripts produced by the copyist. This does not happen with letter scripts, especially personal letters text. The personal letter texts of R. Ng. Ranggawarsita, whose files are stored on the literature.org page that possessed by the Foundation of Sastra Lestari in Surakarta, are not derived from manuscripts, but from original letters written by hand by $\mathrm{R}$. $\mathrm{Ng}$. Ranggawarsita.

Thus, many codicological facts need to be revealed. For example, what is the form or style of the handwritten Javanese script (strip) written by R. Ng. Ranggawarsita. In addition, it can also be disclosed regarding to whom the letters are addressed, what is the subject of the letter, and how the details of the Poet's personal life are reflected in the subject of the letter. Therefore, what is the personal side of the great poet of the Surakarta Palace of R. Ng. Ranggawarsita, which is reflected in the manuscripts of his personal letters, it is very interesting and important to be conducted. The problems that examined in this codicological research include: 1) letter letters, 2) letter language, and 3) letter contents. Further, three aspects that can provide an overview of the background of the life of the poet, who is generally recognized as the greatest and most recent Javanese poet [4].

\section{Research Methods}

This study was in the form of qualitative descriptive, namely research attempts to explore qualitative data and describe the results of the research in a thorough, detailed and nuanced manner [5] [6]. The data in this study were the personal letters text of R. Ng. Ranggawarsita and information related to these letters. The primary data source in this study was the personal letters text of R. Ng. Ranggawarsita, a collection of the Surakarta Sastra Lestari Foundation which has been uploaded on the literature.org page.

On the literature page, the collection of Ranggawarsita's letters is entitled The Correspondence of Rănggawarsita, LOr 2235, c. 1836-44, \# 869. The original versions of these letters are preserved in the Leiden library and are part of the Javaansche brieven van Soerakarta, LOr 2235, c. 1789-1845, \#663. The collection of letters consisted of 28 letters, the letters written by Ranggawrsita were letter No. 2-27, while the other two letters, namely nos. 1 and 28 were addressed to Ranggawarsita.

Data collection techniques with content analysis, namely the collection of research data sourced from documents [7] . Data analysis used the interactive model analysis with three components of analysis, namely data reduction, data presentation, and conclusions or verification, the activities were carried out in an interactive form with the data collection process as a cycle process. The three components of the analysis were data reduction, data presentation, and conclusion or verification, activities are carried out in an interactive form with the data collection process as a cycle process".[8] 


\section{Results and Discussion}

\section{Script Form}

The manuscript of the letters of R. Ng. Ranggawarsita, the collection of the Surakarta Sastra Lestari Foundation, consists of 26 letters, both incoming and outgoing letters. The incoming letter to R. Ng. Ranggawarsita as many as 2, namely from Purbadipura and from Winter. There were 24 outgoing letters, namely: 20 letters to Winter, 1 letter to Mrs. Eming, 1 letter to Purbadipura, and 2 letters to Van Der Am. These letters are personal letters, not official letters. There are even letters that are very personal. If it is assumed that the personal letters were written by the person who wrote the letter, it can be said that the manuscripts of the letters $\mathrm{R}, \mathrm{Ng}$, Ranggawarsita in the collection of the Surakarta Sastra Foundation were written by 3 people, namely R. Ng. Ranggawarsita, Purbadipura's writing, and Winter's writing.

Thus, it can be said that the form of the Javanese script handwritten which becomes the media in these letters is a special characteristic of the writer. Likewise, with the form of the script in the script of the letters of R. Ng. Ranggawarsita is a special character of R. Ng's handwritten form. Handwritten or striped letters or characters are different in shape from printed letters. Letters or characters produced from a printing press will be similar, even if they are printed many times, as long as the print masters are the same, the form will be the same. In contrast, handwritten letters have their own characteristics that cannot be the same between one writer and another. Especially in Javanese script writing, each writer has their own uniqueness in the form of written letters. Therefore, there is specificity of handwritten letters can be a special characteristic of each writer.

The letters that are the object of this study are the personal letters of $\mathrm{R}$. $\mathrm{Ng}$. Ranggawarsita. Therefore, study on the character of R. Ng. Ranggawarsita's personal letters is expected to describe in detail about the characteristics or specificities of the handwritten letters of R. Ng. Ranggawarsita. The results of the description of the handwritten letters of R. $\mathrm{Ng}$. Ranggawarsita can be used to identify and provide information about handwritten scripts by R. Ng. Ranggawarsita.

According to Venny Indria, the Javanese script is divided into three groups, namely: mbata sarimbag, ngetumbar, mucuk eri, and combination [9].

a. The form of the Javanese script, mbata sarimbag, is the Javanese script that similar to

printed brick. The Javanese script in the form of mbata sarimbag tends to be boxy, stiff, with no curved and pointed lines. Writers who use mbanta sarimbag form to write Javane script are usually basic writers or inexperienced writers. The reason is the writing of mbata sarimbag tends to be easier, does not require stylization. This letter form is usually used for printed manuscripts. Meanwhile, for handwritten manuscripts, well-known poets or copyists usually do not use this form, because this form is very simple, so it does not have aesthetic effect.

b. Ngetumbar, namely the Javanese script which tends to be rounded in writing, similar to coriander. Generally, the shape still refers to mbata sarimbag, but uses bullous stylization on the curves and corners of the letters.

c. Mucukeri, namely the Javanese script which tends to be sharp, stylized at the corners of the letters.

d. Combination, namely the Javanese script which in writing combines two or more Javanese letter forms. Good combination of mbata sarimbag and ngetumbar, mucukeri and ngetumbar, amd others.

Analysis of the form of letters in the manuscript of $\mathrm{R}$. Ng. Ranggawarsita is more focused on: dentawyanjana. 
The opinion of Venny Indria's is used to analyze the form of the script on $\mathrm{R}$. $\mathrm{Ng}$. Ranggawarsita's letters, it can be said that the letter form written by R. Ng. Ranggawarsita is the combination of mucukeri and ngetumbar that is written on the right side with slope of about 50 degrees. The form of script appears in eri on R. Ng. Ranggawarsita's letters can be seen in this following script form:

$\boldsymbol{c a}$

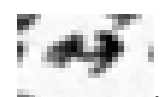

$\boldsymbol{m a}$

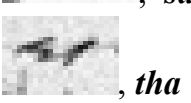

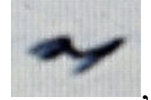

$\boldsymbol{s a}$

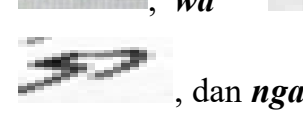

, la
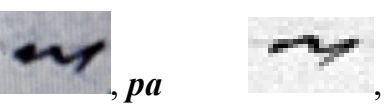

Moreover, the forms of mucuk eri can be seen in both suku and pangkon namely the kula nuwun writing

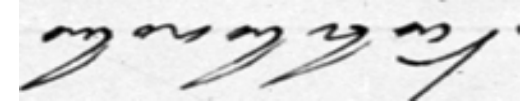

The shape of script that trembles is the indentation of pen that tends to form an arc, not an angle. The speed of the pen moving from vertical to horizontal and from horizontal to vertical does not form an angle, but rather forms an arc. This is clear in all denta wyanjana letters,

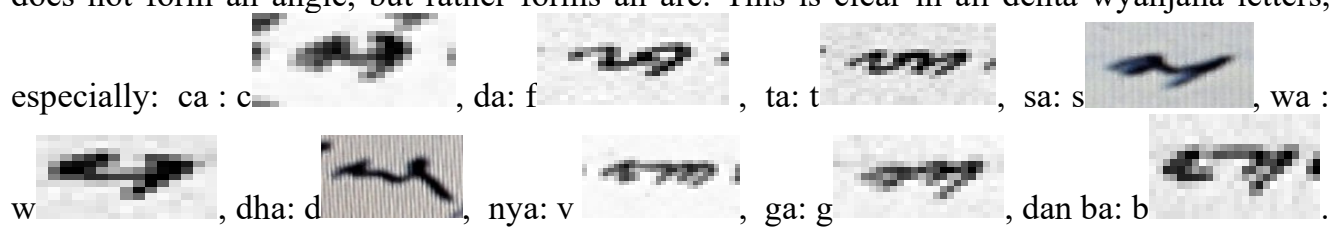

\section{The Language of Letter}

The letters written by Ranggawarsita are in Javanese. Javanese language has a variety or level of speech, namely the Ngoko, Madya, and Krama levels. One of the functions of this speech level is to show someone's respect for the person being spoken to and the person being talked about. Ranggawarsita's letters all use Javanese krama, but the respect that is reflected in the letter addressed to different people shows a different attitude of respect.

The letters addressed to Winter show that Ranggawarsita is very respectful of Winter. This is shown in the use of various Javanese languages to reveal the respect on Winter by using the expression:

atur sêmbah sungkêm kawula, pun Ngabèi Rănggawarsita, ingkang mugi-mugi kaonjuk ing sangandhap pinarakan paduka kangjêng rama. (Letter argued on 9 Sèptèmbêr 1842, literary collection letter.org No. 26)[10]. The words used to refer to the speaker's self (Ranggawarsita) use the krama andhap vocabulary which has function to humble oneself and at the same time respect the person is being spoken to. The vocabulary of krama andhap (low manners) used by Ranggawarsita, among others: atur (menghaturkan), sembah (sembah), sungkem (bakti), kawula (hamba).

Meanwhile, the words used and addressed to Winter used krama vocabulary and krama Inggil vocabulary, as seen in the series of ingkang mugi-mugi kaonjuk ing sangandhap pinarakan paduka kangjêng rama'which hopefully is received under near paduka ramanda'. The vocabulary in the phrase ingkang mugi-mugi (hopefully) is krama, kaonjuk (accepted), sangandhap (below), pinarakan (near), paduka (excellency), kangjeng rama (Father). The words used by Ranggawarsita show how much Ranggawarsita respects Winter. Even though Winter is on the other hand in the language field is Ranggawarsita's student.[11] 
The use of this form of language shows that the sender of the letter has great respect for the person to whom the letter is sent, namely Winter, and indicates his position under Winter or that the letter writer positions himself under Winter. Meanwhile, the use of the muda karma style which refers to Winter uses muda karma which is formed with the vocabulary of karma Inggil, it indicates that the person who received the letter, namely Winter, was a very respectable person whose position is higher than the person who send the letter.

The use of Javanese in the letter delivered by Ranggawarsita is different from the letter that argued to Rahadèn Angabèi Purwadipura, his colleague at the Surakarta palace. The language that used to express oneself and address Rahadèn Angabèi Purwadipura (letter no.3) is as follows.

Kawula Radèn Ngabèi Rănggawarsita, abdi dalêm kaliwon ing kadospatèn. Angaturi uninga ing panjênênganipun kyai bêkêl, kangmas Rahadèn Angabèi Purwadipura

The variety of languages used by Ranggawarsita includes the variety of mudha krama. The form of muda krama to pronounce himself is muda krama which is formed with the vocabulary of krama andap and it shows Ranggawarsita's respect for the person to whom the letter is sent. Meanwhile, the krama young vocabulary which refers to the person who is being greeted and it is formed with krama Inggil vocabulary. This points out the respect for the person being greeted. However, the vocabulary used by Ranggawarsita to honor the person that he is talking to is merely necessary, it is not exaggerated as the language that addressed to Winter.

In the letters that have been written, Ranggawarsita also often uses language of kedaton, which is language used in the walls of the Surakarta palace. For example, abdi dalem kaliwon, a position as a court retainer; Kadospaten (kadipaten) is the vocabulary form of krama ndesa, which is the vocabulary of krama used by villagers but it is commonly used in Basa Kedaton. Other languages of the palace used are: Kadhawahan timbalan dalem (king's order), karsa dalem (king's will), kawula (servant), andikakaken, (to say) dhawahing timbalan dalem (the king's will), tenggak saos (keep), denten, kapiji sowan (desired to face), panepen (place of meditation), sandika (ready), and so on.

\section{The Body of Letter}

A very essential part of a letter is the body of the letter. The letter of Ranggawarsita can be divided into 3, namely letters related to work matters, debt securities, and letters of request. Work-related letters are mostly addressed to Winter, a Dutch interpreter. The letter that associated with work, and, it is related to Ranggawarsita as a Surakarta court poet, who has expertise in languages and literature. Ranggawarsita's expertise in literature is undoubtedly and it is proven by the many works which he has created, he has created around 70 works covering various fields, including philosophy, history, prophecy, genealogy, education, science, puppetry, and dictionaries [12]. His expertise in the field of language can be seen from the beauty of the strands of language in his works.

Dealing with the 26 letters contained in the literature web.org, 14 of them contain those related to his work as a linguist and literary expert. In the letters, Winter is the employer and Ranggawarsita receives the job. The work that Ranggawarsita received generally explained the meaning of difficult words which are generally in the form of kawi (ancient Javanese) words and translated poetry verses.

Letter no. 14 [13]contains Winter's request to Ranggawarsita to explain the meaning of kawi words. Meanwhile, letter No. 15 [14]contains the assigning to translate kawi words by Ranggawarsita to Winter. In carrying out his work, namely interpreting kawi words, Ranggawarsita receives a reward in the form of money. Letter No. 23 [15] explains that 
Ranggawarsita receives a reward of Rp. 20, - after doing the assignment that has been assigned by Winter.

Ranggawarsita does not merely gain a reward from Winter for helping to explain the meaning of difficult words, but also receive the same reward from the pastor van der Plis. In letter No. 18[16], Ranggawarsita borrows Rp. 10, - to Winter and will be returned upon receiving wages from Phan Der Phlis. Ranggawarsita is a Javanese teacher for Phan Der Phlis on the orders of the king, this is explained in letter No.3, namely the letter Ranggawarsita to R.Ng. Purwadipura.

The correspondence between Ranggawarsita and Winter does not only contain the requests from Winter to explain the meaning of Javanese words, but also contains debt. Ranggawarsita's debt to Winter for various purposes. Actually, this debt is related to work relationships. In letter No. 26, it is asserted that Ranggawarsita borrows money from Winter in the amount of Rp. 25.00, - to pay his obligations to the State. The debt will be replaced by doing work if Winter still provides more work, but if it is not given the job, Ranggawarsita will pay the debt at a later date, namely on Eid of fasting.

In addition to debt for various purposes, Ranggawarsita also has a large debt, namely Rp. 600.00 , - to Mrs. Eming. This debt is not explained for what purpose. This debt is bound by a letter of agreement in letter No.2. [17] The agreement letter states that the repayment of the debt shall be undertaken in installments from the produce of the land covering an area of two ejung. One year, the installments are paid in two times, with an installment rate of Rp. 50, -. This debt will be paid in full for 12 years including interest. Thus, the total amount that must be returned by Ranggawarsita is Rp. 1,200.

The letter of Ranggawarsita does not merely contain work and debt problems, but also problems of daily life carried out between members of the society, namely helping each other. In one of his letters, namely letter No. 5[18], Ranggawarsita asks the drink to Pastor Van der Am. The letter is stated about the writer of letter, Ranggawarsita, asks for two bottles of brandewin and two bottles of red wine, but it is not explained the purpose.

\section{Conclusion}

The findings of this study were physically the personal letters text of R. Ng. Ranggawarsita that handwritten (strip) in the ink on paper in Javanese script and Javanese alphabet. The form of the Javanese letter used was a combination of mucuk eri (pointed) and ngetumbar (round) which was written leaning to the right with a slope of about 50 degrees. The language used was the Javanese language of the muda krama (soft manner).

Besides, the vocabulary of Krama Inggil and Krama Andhap was also used in the vocabulary of Kedaton (vocabulary used in the palace environment). Almost all of Ranggawarsita's letters were argued to his Dutch colleagues in connection with his profession as a linguist. In addition, the letters also contained the debts and relationships among members of society in daily life.

\section{References}

[1] T. Pudjiastuti, "Kajian Kodikologis atas Surat Sultan Kanoman, Cirebon,” vol. 9, no. 1, pp. 51-61, 2007.

[2] T. N. Ma'mun and H. Hazmirullah, "Sepak Terjang Bagus Rangin dalam Surat Dipati Natadireja Kepada Daendels (1808),” Jumantara J. Manuskrip Nusant., vol. 11, no. 2, p. 163, 2020, doi: 10.37014/jumantara.v11i2.957. 
[3] H. H. Sunliensyar, "Empat Naskah Surat Incung pada Tanduk Kerbau dari Mendapo Rawang, Kerinci: Suntingan Teks dan Terjemahan,” Jumantara J. Manuskrip Nusant., vol. 11, no. 2, p. 79, 2020, doi: 10.37014/jumantara.v11i2.939.

[4] "Nancy Florida.pdf.".

[5] E. G. Y. S. Lincoln,.., \& Guba, No TitleNaturalistic Inquiry. 1985.

[6] H. B. Sutopo, "Metodologi Penelitian Kualitatif: Dasar Teori dan Terapannya dalam Penelitian." UNS Press, Surakarta, pp. 62-63, 118-120, 2006.

[7] R.K.Yin, "Case study research: Design and methods." Sage Publications, Beverly Hills, CA, p. 57, 1987, doi: -.

[8] A. Miles, M., \& Huberman, Qualitative Data Analysis. London: SAGE Publications., 1992.

[9] V. Indria, "No Title," http://staffnew.uny.ac.id/upload/132303685/pendidikan/hand-outkomprehensi-tulis.pdf. .

[10] Rănggawarsita, "Surat Rănggawarsita kepada Winter, 9 September 1842.” 1842.

[11] S. E. Cipta, "No TitRanggawarsita dan Sufisme Jawa: Studi Pemikiran Bagus Burham Terhadap Budaya Islam Jawa (1823-1870)le," Al-Mada J. Agama Sosisal dan Budaya, vol. Vol. 3 No, 2020.

[12] A. Tedjowirawan, "Menelusuri Kebesaran Pujangga R.Ng. Ranggawarsita Melalui KaryaKaryanya." FIB UGM, Yogyakarta, p. 62, 2009.

[13] Rănggawarsita, "Rănggawarsita kepada Winter, 16 Desember 1842.” 1842.

[14] Ranggawarsita, "Surat Rănggawarsita kepada Winter, 16 November 1842.” 1842.

[15] Rănggawarsita, "Surat Rănggawarsita kepada Winter, 31 Oktober 1842." 1842.

[16] Ranggawarsita, "Surat Rănggawarsita kepada Winter, 22 Desember 1840.” 1840.

[17] Rănggawarsita, "Surat Rănggawarsita kepada Nyonyah Eming, 13 Maret 1836." 1836.

[18] Ranggawarsita, "Surat Rănggawarsita kepada Van Der Am, c. Juni 1844.” 1844. 